\title{
Why fishers end up in social-ecological traps: a case study of Swedish eel fisheries in the Baltic Sea
}

\author{
Emma Björkvik $^{1}$, Wiebren J. Boonstra ${ }^{1}$ and Jonas Hentati-Sundberg ${ }^{1,2}$
}

\begin{abstract}
Unsustainable fishing can be surprisingly persistent despite devastating social, economic, and ecological consequences. Sustainability science literature suggests that the persistence of unsustainable fisheries can be understood as a social-ecological trap. Few studies have explicitly acknowledged the role of historical legacies for the development of social-ecological traps. Here, we investigate why fishers sometimes end up in social-ecological traps through a reconstruction of the historical interplay between fishers' motivations, capacities, and opportunities to fish. We focus on the case of a Swedish fishery targeting the critically endangered European eel (Anguilla Anguilla) in the Baltic Sea. We performed the case study using a unique quantitative data set of social and ecological variables that spans over eight decades, in combination with earlier literature and interviews with fishers and fisheries experts. Our analysis reveals that Swedish archipelago fishers are highly dependent on the eel to maintain their fishing livelihood. The dependence on the eel originates from the 1930s, when fishers chose to intensify fishing for this species to ensure future incomes. The dependence persisted over time because of a series of changes, including improved eel fishing technology, heightened competition over catch, reduced opportunities to target other species, implementation of an eel fishing license, and the fishers' capacity and motivation to deal with dwindling catches. Our study confirms that social-ecological traps are path-dependent processes. In terms of management, this finding means that it becomes progressively more difficult to escape the social-ecological trap with the passage of time. The longer entrapment endures, the more effort it takes and the bigger change it requires to return to a situation where fishers have more options so that unsustainable practices can be avoided. We conclude that fisheries policies need to be based on the premise that unsustainable fishing emerges through multiple rather than single causes.
\end{abstract}

Key Words: causal historical analysis; European eel; fisheries management; mixed methods; path dependency

\section{INTRODUCTION}

Indeed, what is fascinating - and also tragic - about the fishing industry is that it so actively participates in its own annihilation (McGoodwin 1990:17).

Capture fisheries have persistently reduced fish populations throughout human history and threatened species to extinction countless of times (e.g., Jackson et al. 2001, Pauly et al. 2002, Roberts 2007). Such unsustainable practices come about through complex causal processes that not only involve fishers, governments, industries, and consumers, but also depend on temperature, birds, seals, toxins, and a number of other ecological and biological conditions (e.g., Ludwig et al. 1993, Boonstra and Österblom 2016). The reasons why fishers continue to risk their own and future fisher generations' livelihoods are thus, besides tragic, also elusive (McGoodwin 1990).

The metaphors of "tragedies" and "social-ecological traps" are frequently used to explain the persistence of unsustainable fisheries. These concepts capture how individuals can, collectively and unintentionally, contribute to sustainability problems such as overexploitation and ecosystem degradation. Traps and tragedies feature prominently in academic discussions since the 1970s on how to manage commonly shared natural resources (Hardin 1968, Platt 1973, Ostrom et al. 2002, Cumming 2018). The tragedy metaphor, famous since Hardin's article "The tragedy of the commons" (Hardin 1968), is heavily criticized for overlooking the possibility and diversity of common-pool resource management arrangements, and the potential of social learning, human adaptation, and transformation (McCay and
Jentoft 1998, McCay 2002). The metaphor of social-ecological (SE) traps leaves more room for changing conditions and, for this reason, is often preferred over the tragedy metaphor in the sustainability science literature. In contrast to the idea of tragedies, the literature on SE traps views unsustainable use of common property not as the default outcome of human action (Haider et al. 2018).

SE traps are situations in which interactions between humans and their environment reinforce unsustainable outcomes (Cinner 2011, Enfors 2013, Haider et al. 2018). Many studies of SE traps describe and explain these interactions in one particular moment in time (Steneck et al. 2011, Hänke et al. 2017). Insights from these studies can be used to create typologies of traps (see Cumming 2018 for an example) and to develop management strategies of how to escape traps. Previous studies also emphasize the importance of history and argue that traps evolve through the co-occurrence of certain conditions at specific points in time (Boonstra and de Boer 2014). However, few empirical studies explicitly address the historical causality in the development of traps (but see Laborde et al. 2016 for an excpetion).

Here, we present insights on why fishers end up in SE traps through a reconstruction of the historical interplay between Swedish Baltic fishers and their environment. We carried out this reconstruction using a theoretical framework in which we conceptualize SE traps as path-dependent processes that evolve through the interplay of fishers' motivations, capacities, and opportunities to fish (Boonstra et al. 2016). We apply this framework to a case of Swedish fishers who target the critically

${ }^{1}$ Stockholm Resilience Centre, Stockholm University, Stockholm, Sweden, ${ }^{2}$ Department of Aquatic Resources, Institute of Marine Research, Swedish University of Agricultural Sciences, Lysekil, Sweden 
endangered European eel (Anguilla anguilla; hereafter eel). Through a combination of fisheries statistics, interviews, and earlier literature, we trace the historical development of this fishery and reveal how fishers have become more and more dependent on the eel to maintain their fishing livelihood.

\section{CASE STUDY BACKGROUND}

Eels are catadromous and can live for $>80$ years. They are born in saltwater, migrate to freshwater where they grow into adulthood, and then migrate back to the ocean to spawn. Eels caught in the Baltic Sea hatch in the Sargasso Sea, located in the western part of the North Atlantic Ocean, northeast of Cuba and Bahamas. Once the eels hatch, they drift with ocean currents toward European estuaries, where they start migrating to freshwater rivers and lakes. This global journey may take 5 to 20 years. Upon reaching adulthood, they become so-called silver eels, which is a biological transformation that ends in their migration back to the ocean. Once they reach the Sargasso Sea, they spawn and then presumably die. Throughout their life, eels are critically threatened by a variety of anthropogenic factors, and the species is therefore considered to symbolize the effects of global environmental change (Drouineau et al. 2018).

The eel population is very difficult to monitor because of its extensive habitat and complex life cycle (Dekker 2000) but has probably been in decline since the early 1800s (Dekker and Beaulaton 2016). The recruitment of new eels showed a small but significant increase in 2010-2011, yet it is still low compared to historical levels (ICES 2018), and the species remains listed as critically endangered by the International Union for the Conservation of Nature (Jacoby and Gollock 2014) and the Swedish ArtDatabanken (ArtDatabanken 2015). The causes of the decline are uncertain but likely involve fishing along the European coast and in freshwater systems, habitat loss due to hydro power construction, pollution, diseases, and changed ocean conditions (ICES 2018). To reverse the decline and protect the eels, the European Union adopted a recovery plan in 2007 obliging all member states to implement eel management plans (EC 2007). However, management is extremely difficult because of limited knowledge of population dynamics, conflicting interests among stakeholders, lack of international coordination, and disagreements on appropriate measures (Dekker 2016). The scientific advice, therefore, takes a precautionary approach, which involves reduction of all anthropogenic impacts to as close to zero as possible (ICES 2017).

Sweden has a long history of eel fishing and is today one of the countries in Europe catching the most eels (ICES 2018). In Sweden, the eel is valued for cultural reasons. For example, it is served as a traditional dish during Christmas and other celebrations. It also represents an economically important target species for small-scale fisheries (Neuman and Píriz 2000, Stage 2015). The cultural and economic value of the eel, together with its status as critically endangered, form a dilemma for Swedish policy makers. There is willingness to maintain eel fisheries, but there is also the realization that continued eel fishing threatens the survival of the species and the long-term development of archipelago fisheries (Stage 2015). As a compromise, eel fishing is permitted in the Baltic Sea and in freshwater only during a restricted season of 90 days and only for fishers with a specific fishing license. No new fishers can enter eel fisheries because a license can neither be applied for nor transferred from fisher to fisher. Some researchers argue that this compromise mitigates the negative consequences of the fisheries rather than achieving conservation objectives (Svedäng and Gipperth 2012).

The majority of eels in Sweden are caught using large, passive fish traps called pound nets by fishers operating in the southern and southeastern parts of the Baltic coast (Bergenius et al. 2018; Fig. 1). Eels are also caught using smaller types of traps, but the pound net represents the major eel fishing gear. For our case study, we specifically examine the pound net fishery in Kalmar County (Fig. 2) that is one of the most important eel fishing regions in terms of catch volumes (Ojaveer et al. 2007, Dekker et al. 2018). The pound net fishers in Kalmar are typical place-based, small-scale, "archipelago" fishers (Boonstra and Hentati-Sundberg 2016). They mostly use $<10$-m vessels, fish on private waters close to their home harbor on a seasonal basis, often combine fishing with other occupational activities, and run their fishing business on a principle of keeping costs low. They frequently use other types of gear besides pound nets to catch other species such as cod (Gadus morhua), herring (Clupea harengus), perch (Perca fluviatilis), and whitefish (Coregonus spp.).

Fig. 1. Map of the location of Kalmar County in Sweden.

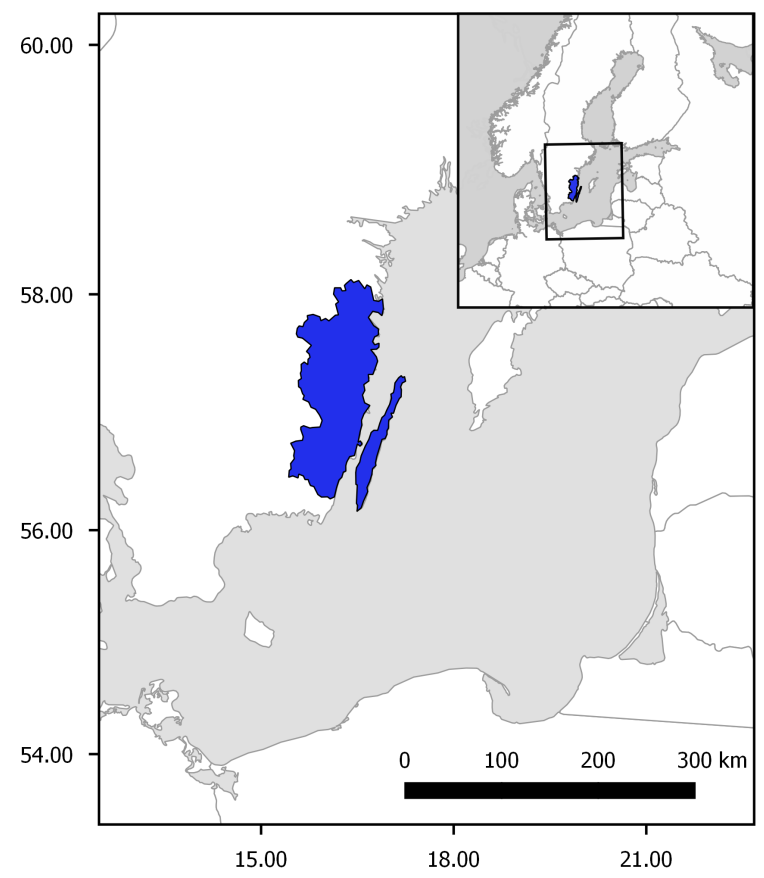

\section{THEORETICAL FRAMEWORK}

SE traps feature self-reinforcing mechanisms and can be conceptualized as path-dependent processes (Boonstra and de Boer 2014, Enqvist et al. 2016, Haider et al. 2018). Path dependency addresses the causal force of history and highlights how time is critical for the (re)production of social processes (Mahoney 2001). The phenomenon of path dependency applies not only to social but also to ecological processes and is analogous 
to what is called a "hysteresis effect" (Scheffer et al. 2001). Acknowledgment of path dependency in SE traps suggests that scholars not analyze SE traps as outcomes but as processes (Boonstra and de Boer 2014).

Fig. 2. Pound net construction. (A) The pound net viewed from above (Nilsson 1977). The pound net can be placed at depths up to $10 \mathrm{~m}$, and the fish is led into the first part of the trap, called a "house", by leading arms. In turn, the house leads the fish into a net cone, which is the second part of the trap. The leading arms can be up to a few hundred meters while the house can be around $30 \mathrm{~m}^{2}$. (B) Two fishers collect catch from the cone (photo used with the permission of Hans Dahlqvist).

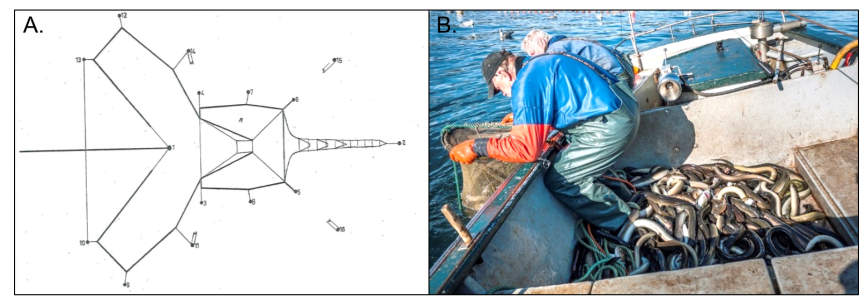

Path-dependent processes emerge from "critical junctures" representing moments in time when individuals or groups have several available opportunities for action from which to choose (Pierson 2000). These opportunities are shaped by previous development, which is theorized as "antecedent conditions". When an opportunity, or path, is selected at the critical juncture, it becomes progressively more difficult to arrive at a situation in which multiple alternatives are available again (Collier and Collier 1991). Once a path-dependent process has been entered, each step along a specific path diminishes the likelihood that an alternative path will be taken. In other words, after a critical juncture, the process becomes self-reinforcing and enters a phase of "structural persistence" (Mahoney 2001).

We study SE traps as path-dependent processes by identifying the diversity of human responses to a changing environment. In line with Boonstra et al. (2016), we view human responses as determined by motivations, capacities, and opportunities. Opportunities are the options available to a person based on the environment in which she or he is situated, and motivations concern the deliberate, habitual, and emotional reasons that propel people to act (Haidt 2001). Capacities are the means, in terms of social, cultural, economic, and natural capital (Bourdieu 1986), with which people act. In summary, opportunities define the physical, social, and cultural constraints for action, while motivations and capacities filter which opportunities a person can seize (Boonstra et al. 2016). Moreover, actions affect opportunities, motivations, and capacities over time. Opportunities, motivations, and capacities are thus both outcomes and causes of human responses to change (Giddens 1984).

\section{METHODOLOGY}

We reconstructed the historical development of the Kalmar pound net fishery through counterfactual reasoning from outcome to cause (Walters and Vayda 2009, Walters 2012). To do so, we identified interactions between fishers' motivations, capacities, and opportunities to explain the persistence of eel fishing, and used these interactions to distinguish specific phases in the process of entrapment. Our analysis is based on both quantitative and qualitative data collected iteratively between 2013 and 2017. The quantitative data constitute Swedish official fisheries statistics on catches, number of fishers, gear value, and fish price, covering the years 1931 to 2016 (see Appendix 1 for more details). We used these statistical materials to construct time series of the pound net fishery.

The qualitative data comprise semistructured interviews with fishers and fisheries experts, and two published ethnographic studies of eel fishers in Kalmar County (Thornstróm 1978, Selling and Holmer 2007). In addition to these data sources, we interviewed seven fishers (ages 49, 49, 61, 65, 68, 68, and 76) to identify motivations and to add local context and nuance to the statistical materials. The fisher interviews were performed during 2013 in the fishers' homes, and all interviewees had been fishing eel for more than two decades. All but one fisher were active commercial fishers during the time of the interview. We structured and coded the interviews around the following themes: organization and diversity of fishing practices, opinions about the development and management of fisheries, and interdependence on the environment (Boonstra and HentatiSundberg 2016). We complemented the fisher interviews with the ethnographic studies by Selling and Holmer (2007) and Thornström (1978). Furthermore, we interviewed one fisheries scientist and two fisheries directors (one retired and one active) working at the Kalmar County board. These expert interviewees recommended which fishers to interview, provided information about the general development of archipelago fisheries, and validated the statistical materials. The first author performed and transcribed all the interviews, which are stored in the Stockholm University archive. We used the interview data to create a fictional, ideal-typical description of an eel fisher in a pen portrait (Box 1).

\section{RESULTS}

We present a chronological narrative based on existing literature together with empirical material (Mahoney 1999, Young et al. 2006). The narrative describes an entrapment process through which fishers have become increasingly dependent on the eel to maintain their fishing livelihood. In the following sections, we distinguish three time periods to describe this development in detail. These periods represent the different phases characterizing path-dependent processes: antecedent conditions (1800-1940), critical juncture (1940-1960), and structural persistence (I: 1960 1990, II: 1990-2016; Table 1).

Box 1: A fisher's experience of his livelihood, work, and environment.

The text represents the voice of an ideal-typical eel fisher (Boonstra and Hentati-Sundberg 2016). It is a fictional description based on quotations from fisher interviews and aims to deepen understanding of how Swedish eel fishers perceive themselves, their work, and the wider environment.

Once I learned how to walk, I started to fish. My dad was a fisher, and there was no real alternative. But you also need such a life-long experience to become a successful fisher. You cannot just go 
Table 1. Overview of the entrapment process in the Kalmar pound net fishery, describing the origin and persistence of dependence on the eel to maintain a fishing livelihood. The opportunities, motivations, and capacities explain how eel fishing continued in response to changes in social and ecological conditions.

\begin{tabular}{|c|c|c|c|}
\hline $\begin{array}{l}\text { Path-dependent } \\
\text { phase }\end{array}$ & Year range & Conditions & Opportunities, motivations, and capacities \\
\hline $\begin{array}{l}\text { Antecedent } \\
\text { conditions }\end{array}$ & $1800-1940$ & Market expansion & Opportunities to fish for profit \\
\hline \multirow[t]{2}{*}{ Critical juncture } & $1940-1960$ & Reduced production for subsistence & Motivation to fish to secure future income \\
\hline & & High economic value and abundance of eel & $\begin{array}{l}\text { Opportunities to intensify eel fishing for fishers with motivation and } \\
\text { capacity to maintain a fishing livelihood in the archipelago }\end{array}$ \\
\hline \multirow{4}{*}{$\begin{array}{l}\text { Structural } \\
\text { persistence I }\end{array}$} & $1960-1990$ & Introduction of improved pound net & Opportunities to intensify eel fishing further \\
\hline & & Previous earnings from fishing and subsides & Capacity (economic capital) to invest in improved pound net \\
\hline & & Increase in pound net investments & Motivation to stick with prior investments \\
\hline & & Decline in total eel catch and number of fishers & Opportunities for remaining fishers to control more catch \\
\hline \multirow{3}{*}{$\begin{array}{l}\text { Structural } \\
\text { persistence II }\end{array}$} & 1990-2016 & Various social and ecological changes (see Table 2) & Fewer opportunities to fish other species \\
\hline & & Implementation of eel fishing license & Motivation to continue reporting eel catch \\
\hline & & Decline in individual eel catch & $\begin{array}{l}\text { Capacity (knowledge and skills) and motivation to continue fishing } \\
\text { because it represents a way of life }\end{array}$ \\
\hline
\end{tabular}

somewhere, put down your gear, and expect to catch fish. No, you have to pay attention the wind, the currents, and how the fish moves. That kind of knowledge is hard to obtain if you do not come from a fisher family. But even for me, who has it in my blood, it is a struggle to survive. I keep thinking: people in the archipelago have been able to make a living out of fishing for hundreds of years, why should it be harder now? It should be easier, with all the technological development, but actually it feels like it has become worse and worse.

I am probably the last fisher in my family, which makes me a bit melancholic. I could probably teach someone to become a fisher, but I do not think it would be easy to find that someone. It takes a lot of investment in the beginning, and I think it will be hard to make enough money to get those investments back. There are also many more comfortable occupations available today. Life as fisher is not easy; the work you put into it does simply not pay off. We who are left just keep doing it because we want to continue living as we've always done.

There are fewer fish in the sea today compared to when I began to fish. Pike and perch, for example, have declined in the last 15 years as the cormorants have grown in numbers. These birds can eat huge amounts of fish, and there is no way we can compete with them. The seals are also just too many. Soon it will be a complete waste of time to fish. The seals eat the fish straight from my gear and destroy the gear while eating. Next to this, there is no point in catching the fish that are still out there, like herring, because no one wants to buy them for a decent price. Then we have fisheries regulations. They control every little thing you do. As soon I put on my boots and step into my boat, I have broken some rule. I probably break a rule every day just because I cannot keep count of all of them. In the past, there was more freedom. Now you cannot do anything, and that is hard; sometimes it is extremely frustrating...

What is left of the archipelago fisheries these days is eel fishing. Sure, other species are also bringing in money, but the eel is my main income right now. Last year I got over $80 \%$ of my income from eel, while in the 1980s, my income was $80 \%$ based on cod and $20 \%$ on eel. At this moment, I think I would not be able to continue fishing without the eel. Maybe I could expand and fish more of some other species, but it would not be enough to make a decent income. The status of the eel is worrisome, and the immigration of eels to the Baltic Sea has been low. Maybe eel fisheries in France and Portugal are to blame; maybe there are too few eels coming from the Sargasso Sea; or maybe a lot of eels die because of the hydro power plants. It is hard to say. One thing I do know, though, is that we fishers want healthy fish stocks more than anyone else.

\section{Antecedent conditions (1800-1940)}

The antecedent condition that crucially affected the development of the pound net fishery is the transition from production for subsistence to fishing for markets. In his thesis from 1978, anthropologist Thornström describes how production for subsistence was gradually replaced by fishing for markets (Thornström 1978). He studied this transition in a community in the northern part of Kalmar archipelago and points out that livelihoods there had historically been based on combinations of fishing, farming, and hunting for subsistence. Cash-based fish markets had little influence on archipelagic communities up until the early 1800 s, but then became increasingly important throughout the 1800 s.

With the beginning of the 20th century, cash-based fish markets expanded rapidly, yet many Swedish archipelagic communities continued to fish for subsistence only. Indeed, some of our respondents described how their predecessors lived and worked in an economy in which self-subsistence was still relatively high. These predecessors were dependent on mainland commodity markets only for luxury goods such as sugar and coffee. The low eel catch and eel catch value per fisher in the 1930s (Fig. 3) also indicate that the fishers' livelihoods were based on several different activities during the end of this period. We can assume that eel abundance was relatively high at this time (Hessle 1933 as cited in Andersson et al. 2012), and that there must have been ample opportunities to catch this fish. It therefore seems safe to say that access to other fish species and terrestrial resources limited fishers' motivation and time to increase eel catch, rather than lack of opportunity. 
Fig. 3. Statistics showing the development of the pound net fishery in Kalmar County, Sweden.
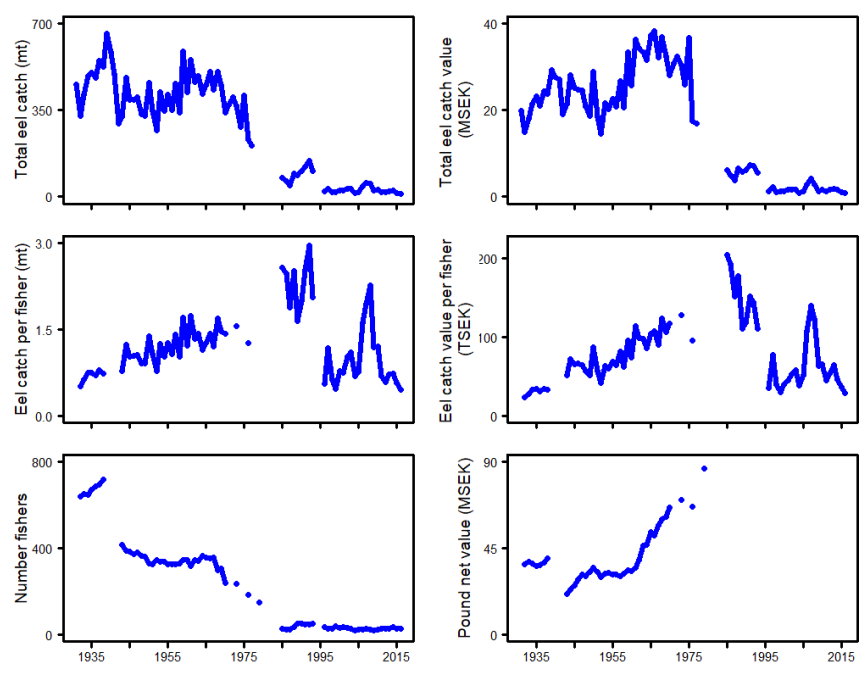

\section{A critical juncture (1940-1960)}

The growing importance of fish markets gradually reduced the amount of time spent on other livelihood activities. Goods traditionally produced through farming, such as meat and milk, started to be bought with earnings from fisheries. The replacement of self-produced goods with commodities, in turn, released more time for fishing, as well as increased the need and motivation for a continuous inflow of money. Toward the mid-20th century, Thornström (1978) found that fishers had three main opportunities to secure future income. One was to quit fishing, move to cities on the mainland, and take job there; a second was to specialize in herring fisheries and invest in trawling to lower the cost of production; and a third was to intensify eel fishing. By now, the eel had a relatively high economic value (Appendix 2), likely because of its attraction on international markets, and was still relatively abundant in the archipelago (Thornström 1978).

We identify the period of 1940-1960 as a critical juncture because fishers could choose among these three opportunities to ensure future income at that moment in time. We also see this contingency in two trends in the statistical materials. First, the number of fishers declined between 1938 and 1946 (Fig. 3). This decline probably came about through fishers leaving the pound net fishery for jobs in industry or switching fishing practices. Second, the eel catch per individual fisher increased. Taken together, these trends suggest that while some fishers chose to quit, others intensified pound net fishing (Fig. 3). The choice of intensifying eel fishing, whether it was made from habit or deliberately, was dependent on the fishers' motivation and capacity to maintain a fishing livelihood in the archipelago. Fishers who chose to move to cities to take a job on the mainland were clearly not willing or able to stay in the archipelago. For those who wanted to stay in the archipelago, trawl fishing was not an attractive alternative because it required much longer trips to new fishing grounds. In contrast to these two alternatives, an intensification of eel fishing could be realized within the boundaries of an archipelagic fishing livelihood (Thornström 1978).

\section{Structural persistence I (1960-1990)}

The dependence on eel as a target species grew over time as the outcome of a specific chain of social and ecological changes and cannot be assigned exclusively to the choice of intensifying eel fishing. The first change in this chain was the technological improvements of the pound net. During the 1950s, the gear was enlarged and its quality improved because of the introduction of nylon (Johnsson and Ericsson 2003). Moreover, the nets could now also be used on hard sea bottoms because of the addition of anchors and grapnels that kept the net floating while fixed to the sea bed. In earlier designs, the net was fixed with poles, which could only be driven into soft sea bottoms.

The improved pound net represented a new opportunity to intensify eel fishing further, and investments in the gear began to increase rapidly in the early 1960s (Fig. 3). At that time, one net could cost between approximately 10,000 and 15,000 Swedish kronor, representing approximately 11,000-16,000 Euros today. These large start-up costs were covered by state subsidies and profits saved from previous fish sales (Thornström 1978). Investments, whether in time or money, are generally considered to motivate people to stick to the activity that the investments make possible (Arthur 1994), a tendency known as the sunk-costs effect (Janssen and Scheffer 2004). We suggest that the increase in pound net investments represent a sunk-costs effect reinforcing fishers' dependence on the eel to maintain a fishing livelihood in the archipelago.

The increasing pound net investments overlap with a $91 \%$ decline in the number of fishers between 1967 and 1985 (Fig. 3). This decline may come from fishers who chose to quit because they could not or did not want to afford the start-up and maintenance costs of the improved pound net (Oskarsson 1987). At this time, fishers were also catching fewer eels because of decreasing eel abundance (Andersson et al. 2012), which negatively affected total eel catch value in the pound net fishery (Fig. 3). And yet, some fishers stopped pound net fishing, others continued to invest. A possible explanation for continued investments is that the large proportion of fishers leaving the fishery masked the decline in eel catch per fisher. The drop in the number of fishers allowed the remaining fishers to control more catch, which likely benefitted their economic situation, despite a declining total eel catch (Telser 1966). This explanation is further supported by the statistical data displaying an increased eel catch and eel catch value per individual fisher between the early 1960s and the beginning of the 1990s, and a stabilization in the number of fishers after 1985 (Fig. 3). In summary, competition over catch and some fishers' lack of capacity, in terms of economic capital, to start or to continue pound net fishing opened up opportunities for other fishers to catch more eels.

\section{Structural persistence II (1990-2016)}

Somewhat counterintuitively, we suggest that the high dependence on the eel continued during the 1990s, even though the eel catch and eel catch value per fisher declined in the mid-1990s (Fig. 3). From the respondents, we learned that opportunities to fish other species became limited in the $1990 \mathrm{~s}$ and 2000s because of several interacting social and ecological 
Table 2 Description of social and ecological changes identified by fishers as affecting their fishing livelihood and leading to reduced fishing opportunities between 1990 and 2016.

\begin{tabular}{|c|c|c|c|}
\hline Change & Explanation & Reference & Perceived effect \\
\hline $\begin{array}{l}\text { Increase in grey seal } \\
\text { (Halichoerus grypus) }\end{array}$ & $\begin{array}{l}\text { Population recovery from hunting and low fertility rates } \\
\text { caused by environmental pollution }\end{array}$ & Harding et al. (2007) & $\begin{array}{l}\text { Destroyed fishing gear, damaged } \\
\text { catch, fewer fish available }\end{array}$ \\
\hline $\begin{array}{l}\text { Increase in great cormorant } \\
(\text { Phalacrocorax carbo })\end{array}$ & $\begin{array}{l}\text { Population recovery from previous extermination in 19th } \\
\text { century and environmental pollution }\end{array}$ & $\begin{array}{l}\text { Herrmann et al. } \\
(2019)\end{array}$ & Damaged catch, fewer fish available \\
\hline $\begin{array}{l}\text { Decrease in fish abundances } \\
\text { (e.g., perch, cod) }\end{array}$ & $\begin{array}{l}\text { Low abundances due to various factors such as } \\
\text { eutrophication, commercial and recreational fisheries, } \\
\text { increased grey seal and great cormorant populations }\end{array}$ & $\begin{array}{l}\text { HELCOM (2018), } \\
\text { Hansson et al. (2018) }\end{array}$ & Fewer fish available \\
\hline $\begin{array}{l}\text { Stricter and more complex } \\
\text { regulations }\end{array}$ & $\begin{array}{l}\text { Increased micromanagement because of European Union } \\
\text { policy efforts to minimize fisheries impact }\end{array}$ & $\begin{array}{l}\text { Hentati-Sundberg } \\
\text { and Hjelm (2014) }\end{array}$ & $\begin{array}{l}\text { More difficult to target multiple } \\
\text { species }\end{array}$ \\
\hline $\begin{array}{l}\text { Higher levels of dioxins in } \\
\text { fatty species (i.e., herring and } \\
\text { salmon (Salmo salar) }\end{array}$ & $\begin{array}{l}\text { High dioxin levels caused by environmental pollution; the } \\
\text { national food agency recommends women and children only } \\
\text { eat fatty species from the Baltic two to four times per year }\end{array}$ & Wiberg et al. (2013) & $\begin{array}{l}\text { Lack of species profitable enough to } \\
\text { target }\end{array}$ \\
\hline
\end{tabular}

changes (Table 2). The continuous high proportion of eel in pound net fishers' total income, in terms of value of catch from all gear types used, also confirms the limited opportunities to target other species (Fig. 4).

Fig. 4. Statistics showing the development of pound net fishers' catch using all gear types. (A) Value of pound net fishers' total catch with all gear types for eel and other species. (B) Pound net fishers' total eel catch using pound nets and other gear types.

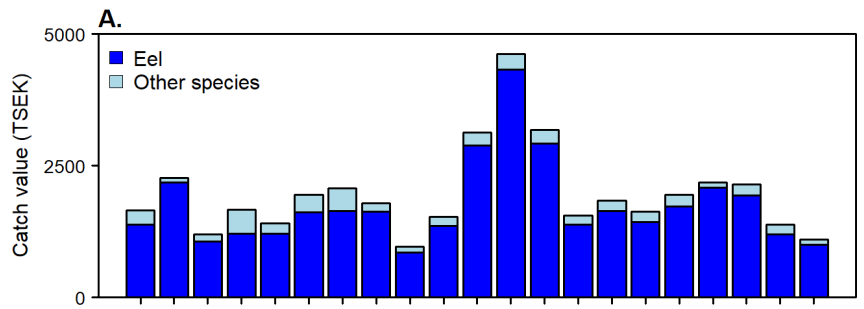

B.

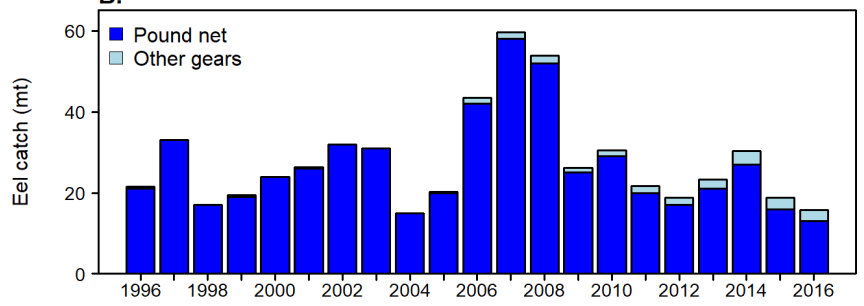

Eel catch per fisher increased after the 1990s and peaked between 2005 and 2008. This peak correlates with the Swedish government's implementation of the eel fishing license. Of a total of 634 applicants, 438 Swedish fishers obtained a license. A license was granted if one's volume of eel catch during the years 20032005 was above a certain threshold, or when one could prove that a certain proportion of one's annual income was derived from eel fishing (SMA 2008). As long as a license holder uses the license and reports eel catches to the government, the license is renewed on a yearly basis; otherwise, it is lost. It is uncertain if, or to what extent, the implementation of the license system and the peak in eel catch per fisher are related, but acquiring and maintaining this license likely motivated fishers to continue eel fishing, perhaps even favoring eel over other species. We consequently suggest that the license system incentivized fishers to continue to target eel and, in so doing, contributed to the further persistence of this fishery.

Eel catch and eel catch value per fisher dropped after 2008 and reached a record low in 2016 (Fig. 3). During this period, the eel price was still high compared to those for other species (Appendix 2 ), yet eel fishing was generally recognized as an unprofitable activity (Stage 2015, STECF 2018). Nevertheless, the number of fishers has remained relatively stable. We suggest that eel fishers persisted after 2008 through various strategies to maintain or increase a certain level of income. Some fishers refined their catch by, for example, smoking fish to maximize the price per unit weight; others took on short-term jobs outside fisheries, and most fishers were cautious about spending money (Box 1; Boonstra and Hentati-Sundberg 2016). Another strategy was to use other gear types to catch eel, which is visible in Fig. 4, showing how the proportion of eel caught with gear other than pound nets has grown since 2010 .

The fishers' perception of fishing as an identity and way of life, and not only as an income activity, further explains their capacity to continue eel fishing in periods characterized by low revenues (Box 1). Their emotional ties to the fishing livelihood suggests that they value their work for nonmonetary reasons and are relatively unsusceptible to economic pressures or incentives (Pollnac and Poggie 2008, Holland et al. 2020). All of the fishers we interviewed grew up in families in which their fathers or other relatives were fishers. From a very young age and throughout many years, they have built up a vast repertoire of experiences, knowledge, and skills required to succeed in catching fish. The time and work it takes to obtain this type of craftsmanship can hardly be overestimated (Mellegård and Boonstra 2020). Once this hard-won capacity is acquired, fishers hate to see it go to waste (Box 1). As our historical reconstruction demonstrates, these fishers have become increasingly dependent on the eel to maintain their fishing livelihood, and several told us that they would probably quit fishing completely if they could not fish eel.

\section{DISCUSSION}

Our historical reconstruction of the development of the pound net fishery in Kalmar County investigates the development of a SE trap comprising fishers who are dependent on a critically 
endangered species to maintain their fishing livelihood. The dependence has grown over time through interactions in opportunities, capacities, and motivations to fish, and these interactions made the trap progressively more difficult to escape. The shrinking potential to change the situation indicates rigidity, which is a common feature of SE traps in general (Scheffer and Westley 2007, Cumming 2018, Haider et al. 2018) and of SE traps in the fisheries context (Steneck et al. 2011, Laborde et al. 2016, Hanh and Boonstra 2018). In what follows, we first elaborate on the possibilities to escape the trap and then suggest a management strategy to avoid this situation in other place-based fisheries. We end with a discussion on how historical reconstructions of SE traps can contribute to the understanding of the origin and persistence of unsustainable fisheries.

We argue that possibilities to escape unsustainability in Swedish eel fisheries are slim for two main reasons. First, the fishers are place-based in the sense that they are emotionally, culturally, habitually, and legally tied to their fishing grounds and fishing livelihood. These ties make it difficult to reduce eel fishing by switching to alternative species on fishing grounds elsewhere. It is frequently suggested that place-based fishers and other placebased resource users tend to use resources sustainably (e.g., McGoodwin 1990, Masterson 2016). However, in cases where opportunities to diversify income activities or access to other resources are limited, bonds to a specific place may represent a barrier for sustainable resource use (Hanh and Boonstra 2018). Second, Swedish eel fisheries represent a relatively small part of the total anthropogenic pressure to which the eel is exposed (Dekker et al. 2018). This situation makes it unlikely that Swedish fishers could prevent the decline in the eel population, and possibly escape their entrapment, on their own account. This finding is confirmed in studies demonstrating that communitybased management to avoid SE traps is most effective in situations where more stationary species are exploited by fewer stakeholders (Ostrom 2009, Steneck et al. 2011).

We suggest, on the basis of our case study, that fishers' livelihoods are especially at risk in place-based fisheries that are characterized by a high dependence on one species on whose biology and ecology fishers have little influence. To avoid the emergence of such situations in other place-based fisheries, we argue that it is imperative for policy makers to maintain fishing diversity. This strategy can be achieved via livelihood diversification (Allison and Ellis 2001), including pluriactivity (Salmi 2005), but also diversity on the level of catch portfolios (Hanh and Boonstra 2018). However, in our case study, Swedish fisheries management discouraged fishing diversity and thereby contributed to continued dependence on the eel. An accumulation of stricter regulations made it more difficult to target multiple species, and the license system incentivized fishers to continue eel fishing and focus time and energy on a single species. Diversity might be better served in the Swedish eel fisheries through a license or quota system that is based on user groups, fishing styles, or regions, rather than treating fishers only as individuals (Jentoft 2000). By assigning licenses or quotas to groups, fishers could retain diversity at a group level, as well as in their fishing practices.

Historical reconstructions of SE traps in fisheries can help to provide insights about fishing diversity, for example, how and why it is marginalized or maintained, and also how it can potentially be facilitated. Our study demonstrates that rigidity of unsustainable SE interactions, such as unsustainable fishing, can be explained as a response to a number of changing and cooccurring conditions. We argue that each of these conditions is critical for rigidity, but they are not sufficient to cause entrapment on their own. It is rather the specific temporal interplay of conditions that matters. For example, if fishing opportunities had not been reduced, archipelago fishers would likely not have become as dependent on the eel as they are today, despite their investments in the improved pound net. The important role of temporality for the emergence of traps implies that there are various pathways to unsustainability. We have identified one pathway here, but more research is needed to account for equifinality.

Next, our study highlights that the link between fishers' practices and the development of target fish populations may not always be as straightforward as is often implied in previous research. For example, it is suggested that investments in fishing technology are linked to overcapacity (Ludwig et al. 1993). In turn, overcapacity is correlated with too high fishing pressure and declining fish abundances, and declining fish abundances lead to further investments to make up for absent catches. This market-driven feedback loop is frequently used to explain unsustainable fishing (e.g., Pitcher 2001). In our case study, this feedback is obscured. Although the eel fishers clearly contributed and continue to contribute to the overall anthropogenic pressure on the eel, their influence on the eel stock is limited, and their fishing livelihood depends on the actions of a number local and global stakeholders with various interests and power.

\section{CONCLUSIONS}

Through a historical reconstruction of the pound net fishery in Kalmar County in Sweden, we have demonstrated how a group of fishers continue to depend on a critically endangered species to maintain their fishing livelihood. Our result confirms that processes of entrapment are path dependent and can be traced through a specific historical interplay of changing social and ecological conditions (Boonstra and de Boer 2014). This overall finding implies that SE traps are hard to prevent because they can be identified in hindsight only, and we think that it might be too much to expect from foresight and planning that fishers and managers could have escaped entrapment in our case. Nevertheless, to avoid similar situations in other place-based fisheries, we suggest that it is necessary for fisheries management to consider and maintain diversity. This strategy would mean ensuring the legal facilitation of livelihood diversification and allowing varied catch portfolios.

This study sheds light on the causal complexity underlying unsustainable fishing. We believe that our and similar case studies of SE traps in fisheries can provide insights on the various pathways to unsustainability. These insights encourage fisheries management to move away from one-size-fits all solutions and develop policies that account for and adapt to changing conditions (Francis et al. 2007, Boonstra and Österblom 2014). Our study also highlights that fish populations are subject to various pressures in addition to fishing, and that fishers can sometimes only do so much to influence the development of these populations. The decline of the eel population, for example, stems from a host of causes, and the Swedish eel fisheries represent one 
relatively small part of the total anthropogenic pressure. To paraphrase McGoodwin (1990:17): the tragedy in our case study is not just that fishers contributed to the decline of the resource they depend upon, but rather that they lacked opportunities, motivation, and capacity to prevent this decline.

Responses to this article can be read online at: http://www.ecologyandsociety.org/issues/responses. php/11405

\section{Acknowledgments:}

We are grateful for the time and information we received from the fishers and fisheries experts interviewed for this study. Valerio Bartolino provided data for the first generation of log books, and we thank four anonymous reviewers, Thorsten Blenckner, Tracy van Holt, and Marloes Kraan for valuable comments on earlier drafts. We also acknowledge that this study builds on a master's thesis written by Emma Björkvik (2013), at the Stockholm Resilience Centre, entitled "Explaining the decline in Swedish Baltic Sea small-scale fisheries: a historical analysis of fishers in their social and ecological context". Emma Björkvik and Wiebren Boonstra are supported by the Nordforsk-funded project Green Growth Based on Marine Resources: Ecological and Socio-Economic Constraints (GreenMAR) and the FORMAS Project Grant (number 2013-1293) "Working knowledge in Swedish coastal fishery Making cultural capital visible for sustainable use of coastal seaand landscapes".

\section{LITERATURE CITED}

Allison, E. H., and F. Ellis. 2001. The livelihoods approach and management of small-scale fisheries. Marine Policy 25 (5):377-388. https://doi.org/10.1016/S0308-597X(01)00023-9

Andersson, J., A.-B. Florin, and E. Petersson. 2012. Escapement of eel (Anguilla anguilla) in coastal areas in Sweden over a 50year period. ICES Journal of Marine Science 69(6):991-999. https://doi.org/10.1093/icesjms/fss094

ArtDatabanken. 2015. Rödlistade arter i Sverige 2015. [Red listed species in Sweden 2015]. ArtDatabanken, Swedish University of Agricultural Sciences, Uppsala, Sweden.

Arthur, W. B. 1994. Increasing returns and path dependence in the economy. University of Michigan Press, Ann Arbor, Michigan, USA. http://dx.doi.org/10.3998/mpub.10029

Baltic Marine Environment Protection Commission (HELCOM). 2018. Status of coastal fish communities in the Baltic Sea during 2011-2016 — the third thematic assessment. Baltic Sea Environment Proceedings 161. HELCOM, Helsinki, Finland.

Bergenius, M., K. Ringdahl, A. Sundelöf, S. Carlshamre, H. Wennhage, and D. Valentinsson. 2018. Atlas över svenskt kustoch havsfiske 2003-2015. Aqua reports 2018:3. Swedish University of Agricultural Sciences, Drottningholm, Lysekil, and Öregrund, Sweden. [online] URL: https:/www.slu.se/globalassets/ ew/org/inst/aqua/externwebb/sidan-publikationer/aqua-reports-Xxxx xx/ aquarapporter/2018/aqua-reports-2018_3_ny.pdf
Boonstra, W. J., E. Björkvik, L. J. Haider, and V. Masterson. 2016. Human responses to social-ecological traps. Sustainability Science 11(6):877-889. https://doi.org/10.1007/s11625-016-0397$\underline{\mathrm{x}}$

Boonstra, W. J., and F. W. de Boer. 2014. The historical dynamics of social-ecological traps. Ambio 43(3):260-274. https://doi. org/10.1007/s13280-013-0419-1

Boonstra, W. J., and J. Hentati-Sundberg. 2016. Classifying fishers' behaviour. An invitation to fishing styles. Fish and Fisheries 17(1):78-100. https://doi.org/10.1111/faf.12092

Boonstra, W. J., and H. Österblom. 2014. A chain of fools: or, why it is so hard to stop overfishing. Maritime Studies 13:15. https://doi.org/10.1186/s40152-014-0015-4

Bourdieu, P. 1986. The forms of capital. Pages 241-258 in J. Richardson, editor. Handbook of theory and research for the sociology of education. Greenwood Press, Westport, Connecticut, USA. [online] URL: http://www.socialcapitalgateway.org/sites/ socialcapitalgateway.org/files/data/paper/2016/10/18/rbasicsbourdieu1986theformsofcapital.pdf

Cinner, J. E. 2011. Social-ecological traps in reef fisheries. Global Environmental Change 21(3):835-839. https://doi.org/10.1016/j. gloenvcha.2011.04.012

Collier, R. B., and D. Collier. 1991. Shaping the political arena: critical junctures, the labor movement, andregime dynamics in Latin America. Princeton University Press, Princeton, New Jersey, USA.

Cumming, G. S. 2018. A review of social dilemmas and socialecological traps in conservation and natural resource management. Conservation Letters 11(1):e12376. https://doi. org/10.1111/conl.12376

Dekker, W. 2000. The fractal geometry of the European eel stock. ICES Journal of Marine Science 57(1):109-121. https://doi. org/10.1006/jmsc.1999.0562

Dekker, W. 2016. Management of the eel is slipping through our hands! Distribute control and orchestrate national protection. ICES Journal of Marine Sciences 73(10):2442-2452. https://doi. org/10.1093/icesjms/fsw094

Dekker, W., and L. Beaulaton. 2016. Climbing back up what slippery slope? Dynamics of the European eel stock and its management in historical perspective. ICES Journal of Marine Science 73(1):5-13. https://doi.org/10.1093/icesjms/fsv132

Dekker, W., A. Bryhn, K. Magnusson, N. Sjöberg, and H. Wickström. 2018. Assessment of the eel stock in Sweden, spring 2018: third post-evaluation of the Swedish Eel Management Plan. Aqua reports 2018:16. Swedish University of Agricultural Sciences, Drottningholm, Lysekil, and Öregrund, Sweden. [online] URL: https://www.slu.se/globalassets/ew/org/inst/aqua/ externwebb/sidan-publikationer/aqua-reports-xxxx xx/ aquarapporter/2018/aquareport2018 16assesmentoftheeel2018 07022. pdf

Drouineau, H., C. Durif, M. Castonguay, M. Mateo, E. Rochard, G. Verreault, K. Yokouchi, and P. Lambert. 2018. Freshwater eels: a symbol of the effects of global change. Fish and Fisheries 19 (5):903-930. https://doi.org/10.1111/faf.12300 
Enfors, E. 2013. Social-ecological traps and transformations in dryland agro-ecosystems: using water system innovations to change the trajectory of development. Global Environmental Change 23(1):51-60. https://doi.org/10.1016/j.gloenvcha.2012.10.007

Enqvist, J., M. Tengö, and W. J. Boonstra. 2016. Against the current: rewiring rigidity trap dynamics in urban water governance through civic engagement. Sustainability Science 11 (6):919-933. https://doi.org/10.1007/s11625-016-0377-1

European Commission (EC). 2007. Council Regulation (EC) No $1100 / 2007$ of 18 September 2007 establishing measures for the recovery of the stock of European eel. Official Journal of the European Union L 248/17. [online] URL: http://data.europa.eu/ eli/reg/2007/1100/oj

Francis, R. C., M. A. Hixon, M. E. Clarke, S. A. Murawski, and S. Ralston. 2007. Ten commandments for ecosystem-based fisheries scientists. Fisheries 32(5):217-233. https://doi. org/10.1577/1548-8446(2007)32[217:TCFBFS]2.0.CO;2

Giddens, A. 1984. The constitution of society: outline of the theory of structuration. Polity Press, Cambridge, UK.

International Council for the Exploration of the Sea (ICES). 2017. European eel (Anguilla anguilla) throughout its natural range. ICES Advice ele.2737.nea. ICES, Copenhagen, Denmark. [online] URL: http://doi.org/10.17895/ices.pub.3440

International Council for the Exploration of the Sea (ICES). 2018. Report of the Joint EIFAAC/ICES/GFCM Working Group on Eels (WGEEL). ICES CM 2018/ACOM:15. ICES, Copenhagen, Denmark. [online] URL: http://www.ices.dk/sites/ pub/Publication\%20Reports/Expert\%20Group\%20Report/acom/2018/ WGEEL/wgeel_2018.pdf

Jackson, J. B. C., M. X. Kirby, W. H. Berger, K. A. Bjorndal, L. W. Botsford, B. J. Bourque, R. H. Bradbury, R. Cooke, J. Erlandson, J. A. Estes, T. P. Hughes, S. Kidwell, C. B. Lange, H. S. Lenihan, J. M. Pandolfi, C. H. Peterson, R. S. Steneck, M. J. Tegner, and R. R. Warner. 2001. Historical overfishing and the recent collapse of coastal ecosystems. Science 293(5530):629-637. http://doi.org/10.1126/science.1059199

Jacoby, D., and M. Gollock. 2014. Anguilla anguilla. The IUCN Red List of Threatened Species 2014. IUCN Global Species Programme Red List Unit, Cambridge, UK. https://dx.doi. org/10.2305/IUCN.UK.2014-1.RLTS.T60344A45833138.en

Janssen, M. A., and M. Scheffer. 2004. Overexploitation of renewable resources by ancient societies and the role of sunk-cost effects. Ecology and Society 9(1):6. http://dx.doi.org/10.5751/ es-00620-090106

Jentoft, S. 2000. The community: a missing link of fisheries management. Marine Policy 24(1):53-60. https://doi.org/10.1016/ S0308-597X(99)00009-3

Johnsson, B., and A. Ericsson, editors. 2003. Smålandskustens skärgård. [The archipelago of the coast of Småland]. Kalmar Läns Museum, Kalmar, Sweden.

Haider, L. J., W. J. Boonstra, G. D. Peterson, and M. Schlüter. 2018. Traps and sustainable development in rural areas: a review. World Development 101:311-321. https://doi.org/10.1016/j. worlddev.2017.05.038
Haidt, J. 2001. The emotional dog and its rational tail: a social intuitionist approach to moral judgment. Psychological Review 108(4):814-834. https://doi.org/10.1037//0033-295X.108.4.814

Hanh, T. T. H., and W. J. Boonstra. 2018. Can income diversification resolve social-ecological traps in small-scale fisheries and aquaculture in the global south? A case study of response diversity in the Tam Giang lagoon, central Vietnam. Ecology and Society 23(3):16. https://doi.org/10.5751/ES-10207-230316

Hänke, H., J. Barkmann, C. Coral, E. Enfors Kaustky, and R. Marggraf. 2017. Social-ecological traps hinder rural development in southwestern Madagascar. Ecology and Society 22(1):42. https://doi.org/10.5751/ES-09130-220142

Hansson, S., U. Bergström, E. Bonsdorff, T. Härkönen, N. Jepsen, L. Kautsky, K. Lundström, S.-G. Lunneryd, M. Overgård, J. Salmi, D. Sendek, and M. Vetemaa. 2018. Competition for the fish - fish extraction from the Baltic Sea by humans, aquatic mammals, and birds. ICES Journal of Marine Science 75 (3):999-1008. https://doi.org/10.1093/icesjms/fsx207

Hardin, G. 1968. The tragedy of the commons. Science 162 (3859):1243-1248. https://doi.org/10.1126/science.162.3859.1243

Harding, K. C., T. Härkönen, B. Helander, and O. Karlsson. 2007. Status of Baltic grey seals: population assessment and extinction risk. NAMMCO Scientific Publications 6:33-56. https://doi. org/10.7557/3.2720

Hentati-Sundberg, J., and J. Hjelm. 2014. Can fisheries management be quantified? Marine Policy 48:18-20. https://doi. org/10.1016/j.marpol.2014.02.021

Herrmann, C., T. Bregnballe, K. Larsson, M. Leivits, and P. Rusanen. 2019. Population development of Baltic bird species: great cormorant (Phalacrocorax carbo sinensis). HELCOM Baltic Sea Environment Fact Sheet 2018. Baltic Marine Environment Protection Commission, Helsinki, Finland. [online] URL: https://helcom.fi/baltic-sea-trends/environment-fact-sheets/ biodiversity/population-development-of-great-cormorant/

Holland, D. S., J. K. Abbott, and K. E. Norman. 2020. Fishing to live or living to fish: job satisfaction and identity of west coast fishermen. Ambio 49(2):628-639. https://doi.org/10.1007/

s13280-019-01206-W

Laborde, S., A. Fernández, S. Chian Phang, I. M. Hamilton, N. Henry, H. Chul Jung, A. Mahamat, M. Ahmadou, B. K. Labara, S. Kari, M. Durand, B. Mark, P. Scholte, N. Xiao, R. Ziebe, and M. Moritz. 2016. Social-ecological feedbacks lead to unsustainable lock-in in an inland fishery. Global Environmental Change 41:13-25. https://doi.org/10.1016/j.gloenvcha.2016.08.004

Ludwig, D., R. Hilborn, and C. Walters. 1993. Uncertainty, resource exploitation, and conservation: lessons from history. Science 260(5104):17-36. https://doi.org/10.1126/science.260.5104.17

Mahoney, J. 1999. Nominal, ordinal, and narrative appraisal in macrocausal analysis. American Journal of Sociology 104 (4):1154-1196. https://doi.org/10.1086/210139

Mahoney, J. 2001. Path-dependent explanations of regime change: Central America in comparative perspective. Studies in Comparative International Development 36(1):111-141. https:// doi.org/10.1007/BF02687587 
Masterson, V. A. 2016. Sense of place and culture in the landscape of home: understanding social-ecological dynamics on the Wild Coast, South Africa. Dissertation. Stockholm University, Stockholm, Sweden. [online] URL: https://www.diva-portal.org/ smash/get/diva2:1044090/FULLTEXT02.pdf

McCay, B. J. 2002. Emergence of institutions for the commons: contexts, situations, and events. Pages 361-402 in E. Ostrom, T. Dietz, N. Dolsak, P. C. Stern, S. Stonich, and E. U. Weber, editors. The drama of the commons. National Academy Press, Washington, D.C., USA.

McCay, B., and S. Jentoft. 1998. Market or community failure? Critical perspectives on common property research. Human Organization 57(1):21-29. http://dx.doi.org/10.17730/ $\underline{\text { humo.57.1.372712415k227u25 }}$

McGoodwin, J. R. 1990. Crisis in the world's fisheries: people, problems, and policies. Stanford University Press, Stanford, California, USA.

Mellegård, V., and W. J. Boonstra. 2020. Craftsmanship as a carrier of indigenous and local ecological knowledge: photographic insights from Sámi Duodji and archipelago fishing. Society and Natural Resources, in press. [online] URL: https://doi. org/10.1080/08941920.2020.1729911

Neuman, E., and L. Píriz. 2000. Svenskt småskaligt kustfiskeproblem och möjligheter. [Swedish small-scale coastal fisheries barriers and opportunities]. Fiskeriverket rapport 2000:2. Swedish Board of Fisheries, Gothenburg, Sweden. [online] URL: https://www.slu.se/globalassets/ew/org/inst/aqua/externwebb/publikationer/ fiv/klab/pm163-fivrapp 00-2.pdf

Nilsson, K. 1977. Bottengarn: konstruktion och fiske. [Pound net: construction and fishing]. Information från sötvattenslaboratoriet Drottningholm 1977(2). Swedish Board of Fisheries, Drottningholm, Sweden.

Ojaveer, H., K. Awebro, H. M. Karlsdóttir, and B. R. MacKenzie. 2007. Swedish Baltic Sea fisheries during 1868-1913: spatiotemporal dynamics of catch and fishing effort. Fisheries Research 87(2-3):137-145. https://doi.org/10.1016/j.fishres.2007.07.010

Oskarsson, B. 1987. Föra från kust till kust. [Föra from coast to coast]. Föra Local History Society, Borgholm, Sweden.

Ostrom, E. 2009. A general framework for analyzing sustainability of social-ecological systems. Science 325 (5939):419-422. https://doi.org/10.1126/science.1172133

Ostrom, E., T. Dietz, N. Dolšak, P. C. Stern, S. Stonich, and E. U. Weber, editors. 2002. The drama of the commons. National Academy Press, Washington, D.C., USA.

Pauly, D., V. Christensen, S. Guénette, T. J. Pitcher, U. R. Sumaila, C. J. Walters, R. Watson, and D. Zeller. 2002. Towards sustainability in world fisheries. Nature 481:689-695. https://doi. org/10.1038/nature01017

Pierson, P. 2000. Increasing returns, path dependence, and the study of politics. American Political Science Review 94 (2):251-267. https://doi.org/10.2307/2586011

Pitcher, T. J. 2001. Fisheries managed to rebuild ecosystems? Reconstructing the past to salvage the future. Ecological
Applications 11(2):601-617. https://doi.org/10.1890/1051-0761 (2001)011[0601:FMTRER]2.0.CO;2

Platt, J. 1973. Social traps. American Psychologist 28(8):641-651. https://doi.org/10.1037/h0035723

Pollnac, R. B., and J. J. Poggie. 2008. Happiness, well-being and psychocultural adaptation to the stresses associated with marine fishing. Human Ecology Review 15(2):194-200. [online] URL: https://www.jstor.org/stable/24707603

Roberts, C. 2007. The unnatural history of the sea. Island Press, Washington, D.C., USA.

Salmi, P. 2005. Rural pluriactivity as a coping strategy in smallscale fisheries. Sociologia Ruralis 45(1-2):22-36. https://doi. org/10.1111/j.1467-9523.2005.00288.x

Scheffer, M., S. Carpenter, J. A. Foley, C. Folke, and B. Walker. 2001. Catastrophic shifts in ecosystems. Nature 413:591-596. https://doi.org/10.1038/35098000

Scheffer, M., and F. R. Westley. 2007. The evolutionary basis of rigidity: locks in cells, minds, and society. Ecology and Society 12 (2):36. https://doi.org/10.5751/ES-02275-120236

Scientific, Technical and Economic Committee for Fisheries (STECF). 2018. The 2018 annual economic report on the EU fishing fleet. STECF 18-07. European Commission, Luxembourg City, Luxembourg. [online] URL: https://ec.europa.eu/jrc/en/publication/ eur-scientific-and-technical-research-reports/2018-annual-economicreport-eu-fishing-fleet-stecf-18-07

Selling, J., and G. Holmer. 2007. Så länge skutan kan gå. Möten med skärgårdens sista fiskare. [As long as the vessel goes. Meetings with the archipelago's last fisherman]. Västervik Museum, Västervik, Sweden.

Stage, J. 2015. The value of the Swedish eel fishery. Marine Resource Economics 30(1):21-34. https://doi.org/10.1086/679465

Steneck, R. S., T. P. Hughes, J. E. Cinner, W. N. Adger, S. N. Arnold, F. Berkes, S. A. Boudreau, K. Brown, C. Folke, L. Gunderson, P. Olsson, M. Scheffer, E. Stephenson, B. Walker, J. Wilson, and B. Worm. 2011. Creation of a gilded trap by the high economic value of the Maine lobster fishery. Conservation Biology 25(5):904-912. https://doi.org/10.1111/j.1523-1739.2011.01717.x

Svedäng, H., and L. Gipperth. 2012. Will regionalisation improve fisheries management in the EU? An analysis of the Swedish eel management plan reflects difficulties. Marine Policy 36 (3):801-808. https://doi.org/10.1016/j.marpol.2011.11.011

Swedish Ministry of Agriculture (SMA). 2008. Förvaltningsplan för ål. [Eel management plan]. Bilaga till regeringsbeslut 2008-12-11, Nr 21 2008-12-09 Jo2008/3901. Swedish Ministry of Agriculture, Jönköping, Sweden. [online] URL: https://www. havochvatten.se/hav/uppdrag--kontakt/publikationer/aldre-publikationer/ ovriga-publikationer-fran-fiskeriverket/2012-11-05-nationellforvaltningsplan-for-al.html

Telser, L. G. 1966. Cutthroat competition and the long purse. Journal of Law and Economics 9:259-277. https://doi. org/10.1086/466627

Thornström, C. G. 1978. Bakom stagnationen: lokal samhället och omvärlden $i$ en svensk skärgårdsby 1500-1975. [Behind the 
stagnation: local community and surrounding world in a Swedish archipelagic village]. Dissertation. Uppsala University, Uppsala, Sweden.

Walters, B. B. 2012. An event-based methodology for climate change and human-environment research. Geografisk TidsskriftDanish Journal of Geography 112(2):135-143. https://doi. org/10.1080/00167223.2012.741890

Walters, B. B., and A. P. Vayda. 2009. Event ecology, causal historical analysis, and human-environment research. Annals of the Association of American Geographers 99(3):534-553. https:// doi.org/10.1080/00045600902931827

Wiberg, K., A. T. Assefa, K. L. Sundqvist, I. T. Cousins, J. Johansson, M. S. McLachlan, A. Sobek, G. Cornelissen, A. Miller, J. Hedman, A. Bignert, H. Peltonen, M. Kiljunen, V. Shatalov, and I. Cato. 2013. Managing the dioxin problem in the Baltic region with focus on sources to air and fish. Swedish Environmental Protection Agency Report 6566. Swedish Environmental Protection Agency, Stockholm, Sweden. [online] URL: https://www.naturvardsverket.se/Documents/ publikationer6400/978-91-620-6566-9.pdf?pid=8228

Young, O. R., E. F. Lambin, F. Alcock, H. Haberl, S. I. Karlsson, W. J. McConnell, T. Myint, C. Pahl-Wostl, C. Polsky, P. S. Ramakrishnan, H. Schroeder, M. Scouvart, and P. H. Verburg. 2006. A portfolio approach to analyzing complex humanenvironment interactions: institutions and land change. Ecology and Society 11(2):31. https://doi.org/10.5751/ES-01799-110231 


\section{Appendix 1.}

\section{Description of the statistical material}

This paper presents time series that represent Swedish official statistics and cover the development of the pound net fishery in Kalmar County from 1931 to 2016. Data of the pound net fishery has been collected and presented in three main formats over the years. First, between 1931 and 1977, primary data was collected by regional interest organizations (called "hushållningssällskap" in Swedish) that support rural development. Fisheries officers at the county boards then gathered this information, adjusted it in accordance with sales notes from fish byers and reported it to the Swedish Statistical Agency (SSA). SSA published the material in statistical yearbooks, which included a specific table of the pound net fishery (Fig. A1.1). Second, between 1970 and 1979, number of fishers and fishing gear were not collected annually by the regional interest organizations and county board fisheries officers. During this period, the fishers were instead obliged to report their occupational status and used fishing gear to SSA every third year. Third, since 1979, fishers have reported catches and fishing effort based on gear type through logbooks. These logbooks are directly sent to the fisheries management agency.

These different formats were compiled into one common format in a Microsoft Access database. The statistics from the year books were digitalized, and the logbook data was accessed, sorted and aggregated based on gear type. The logbook data is comprised of anonymized data per fishing operation from 1980 to 2016 and number of vessels was used as a proxy for number of fishers during this period. This is considered as a reliable proxy because the vessels used in the pound net fishery are rather small and cannot fit more than one to two persons. It is yet possible that the format differences have influenced the dataset. To minimize such influence, the time-series was presented to the fisheries director of Kalmar who was asked validated them. In consultation with the fisheries director and after further investigations, some years were excluded due to low reliability. In summary, the best available information was used to identify the long-term trends of the pound net fishery and measures were taken to validate these trends. An overview of the statistical material is presented in table A1.1 and the raw data in table A1.2 and A1.3. 


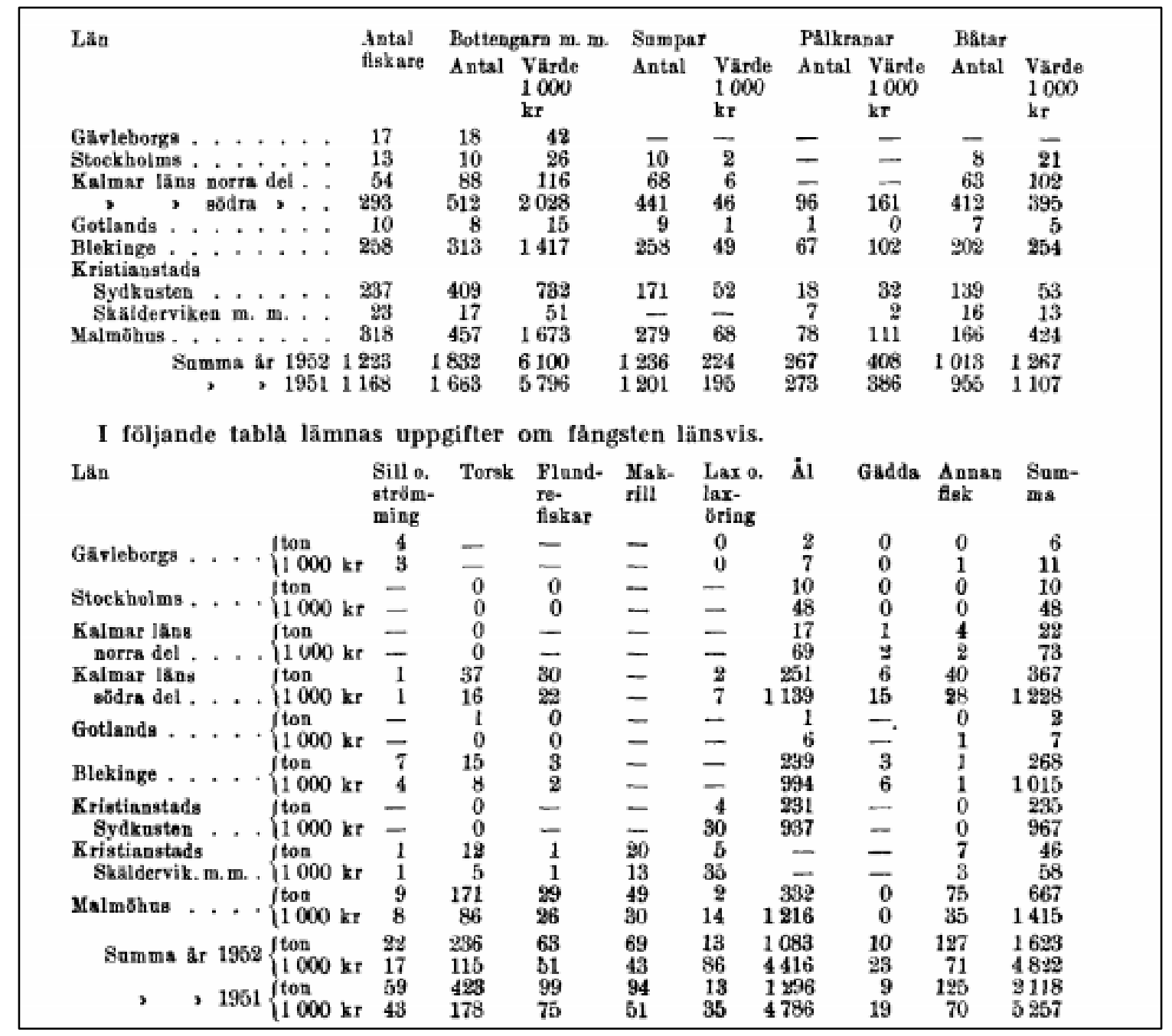

Figure A1.1. Presentation of the pound net fishery in the statistical year books. This example refers to 1952. 
Table A1.1. Overview of the statistical material. Pound net value and price per kilo fish were compensated for inflation using the Swedish Consumer Price Index (CPI).

\begin{tabular}{|c|c|c|c|c|}
\hline \multirow[t]{2}{*}{ Variable } & \multirow[t]{2}{*}{ Unit } & \multirow[t]{2}{*}{ Source } & \multicolumn{2}{|c|}{ Missing values } \\
\hline & & & Year & Reason \\
\hline Catch & $\begin{array}{l}\text { Metric } \\
\text { ton (mt) }\end{array}$ & & & \\
\hline \multirow[t]{2}{*}{$\begin{array}{l}\text { Pound net } \\
\text { fishery }\end{array}$} & & Statistical yearbook & 1978 & $\begin{array}{l}\text { No available } \\
\text { information }\end{array}$ \\
\hline & & Fisheries logbook & $\begin{array}{l}\text { 1979-1984, } \\
1994-1995\end{array}$ & Low reliability \\
\hline \multirow[t]{2}{*}{$\begin{array}{l}\text { Other } \\
\text { gear types }\end{array}$} & & Statistical yearbook & 1931-1978 & $\begin{array}{l}\text { No available } \\
\text { information }\end{array}$ \\
\hline & & Fisheries logbook & 1979-1996 & $\begin{array}{l}\text { No available } \\
\text { information }\end{array}$ \\
\hline \multirow[t]{2}{*}{$\begin{array}{l}\text { Number } \\
\text { fishers }\end{array}$} & Number & Statistical yearbook & $\begin{array}{l}1931,1939- \\
1942,1971- \\
1972,1974- \\
1975,1977- \\
1978\end{array}$ & $\begin{array}{l}\text { No available } \\
\text { information }\end{array}$ \\
\hline & & $\begin{array}{l}\text { Fisheries logbook (number of } \\
\text { vessels as an proxy) }\end{array}$ & $\begin{array}{l}\text { 1979-1984; } \\
1994-1995\end{array}$ & Low reliability \\
\hline \multirow[t]{2}{*}{$\begin{array}{l}\text { Pound net } \\
\text { value }\end{array}$} & $\begin{array}{l}\text { 1000 SEK } \\
\text { (TSEK) }\end{array}$ & Statistical year book & $\begin{array}{l}1931,1939- \\
1942,1971- \\
1972,1974- \\
1975,1977- \\
1978\end{array}$ & $\begin{array}{l}\text { No available } \\
\text { information }\end{array}$ \\
\hline & & Fisheries logbook & $1980-2016$ & $\begin{array}{l}\text { No available } \\
\text { information }\end{array}$ \\
\hline
\end{tabular}

Fish price Price per kilo Swedish official statistics $(\mathrm{SEK} / \mathrm{kg}) \quad$ compiled by HentatiSundberg 
Table A1.2. Raw data of the pound net fishery in Kalmar County. Catch is presented in metric ton and catch value is presented in thousand Swedish krona (TSEK).

\begin{tabular}{|c|c|c|c|c|c|c|}
\hline Yr & $\begin{array}{l}\text { Eel catch } \\
\quad(\mathrm{mt})\end{array}$ & $\begin{array}{l}\text { Eel catch value } \\
\quad \text { (TSEK) }\end{array}$ & $\begin{array}{l}\text { Other catch } \\
\quad(\mathrm{mt})\end{array}$ & $\begin{array}{c}\text { Other catch value } \\
\text { (TSEK) }\end{array}$ & $\begin{array}{l}\text { Pound net value } \\
\text { (TSEK) }\end{array}$ & Fisher \\
\hline 1931 & 455 & 19914 & 156 & 3641 & NA & NA \\
\hline 1932 & 329 & 15017 & 186 & 1971 & 36647 & 642 \\
\hline 1933 & 412 & 18193 & 323 & 2044 & 38248 & 650 \\
\hline 1934 & 487 & 21444 & 219 & 1654 & 37096 & 647 \\
\hline 1935 & 501 & 23153 & 368 & 2615 & 35941 & 671 \\
\hline 1936 & 482 & 21096 & 219 & 1920 & 36203 & 689 \\
\hline 1937 & 551 & 24300 & 189 & 1315 & 37640 & 697 \\
\hline 1938 & 526 & 23830 & 174 & 1394 & 39613 & 720 \\
\hline 1939 & 661 & 29240 & 258 & 2136 & NA & NA \\
\hline 1940 & 583 & 27637 & 271 & 2084 & NA & NA \\
\hline 1941 & 494 & 27114 & 431 & 4340 & NA & NA \\
\hline 1942 & 297 & 19068 & 284 & 3771 & NA & NA \\
\hline 1943 & 323 & 21533 & 120 & 1453 & 21298 & 416 \\
\hline 1944 & 480 & 28202 & 254 & 1861 & 23716 & 391 \\
\hline 1945 & 394 & 25164 & 243 & 1875 & 25898 & 385 \\
\hline 1946 & 391 & 24875 & 262 & 1896 & 28619 & 373 \\
\hline 1947 & 402 & 24546 & 274 & 1765 & 31569 & 382 \\
\hline 1948 & 333 & 20931 & 109 & 561 & 30482 & 367 \\
\hline 1949 & 329 & 18616 & 114 & 550 & 32633 & 360 \\
\hline 1950 & 460 & 28921 & 131 & 654 & 34956 & 332 \\
\hline 1951 & 348 & 18494 & 155 & 639 & 32829 & 327 \\
\hline 1952 & 268 & 14560 & 121 & 687 & 29944 & 347 \\
\hline 1953 & 422 & 21628 & 169 & 900 & 31958 & 340 \\
\hline 1954 & 347 & 20294 & 167 & 780 & 32193 & 337 \\
\hline 1955 & 413 & 22618 & 212 & 1302 & 31275 & 328 \\
\hline 1956 & 351 & 20916 & 294 & 1730 & 31330 & 326 \\
\hline 1957 & 459 & 26798 & 316 & 1945 & 30428 & 326 \\
\hline 1958 & 342 & 20673 & 278 & 1748 & 31866 & 332 \\
\hline 1959 & 589 & 33324 & 313 & 1861 & 33458 & 347 \\
\hline 1960 & 422 & 25820 & 272 & 1705 & 33076 & 347 \\
\hline 1961 & 555 & 36312 & 342 & 2007 & 34967 & 319 \\
\hline 1962 & 466 & 34293 & 321 & 1787 & 38768 & 347 \\
\hline 1963 & 487 & 33339 & 351 & 1798 & 46288 & 342 \\
\hline 1964 & 417 & 31613 & 344 & 1694 & 47089 & 365 \\
\hline 1965 & 450 & 37304 & 394 & 2059 & 53551 & 356 \\
\hline 1966 & 504 & 38286 & 558 & 2420 & 51544 & 354 \\
\hline 1967 & 432 & 32309 & 661 & 2544 & 57007 & 359 \\
\hline 1968 & 505 & 36852 & 482 & 1992 & 60058 & 298 \\
\hline 1969 & 451 & 32510 & 456 & 2214 & 61311 & 306 \\
\hline 1970 & 342 & 28050 & 485 & 3197 & 66475 & 240 \\
\hline 1971 & 373 & 30953 & 342 & 2034 & NA & NA \\
\hline
\end{tabular}




\begin{tabular}{|c|c|c|c|c|c|c|}
\hline 1972 & 403 & 32394 & 343 & 2078 & NA & NA \\
\hline 1973 & 368 & 30397 & 295 & 2050 & 70163 & 237 \\
\hline 1974 & 282 & 25976 & 386 & 2737 & NA & NA \\
\hline 1975 & 411 & 36735 & 365 & 2362 & NA & NA \\
\hline 1976 & 233 & 17537 & 258 & 1812 & 66814 & 184 \\
\hline 1977 & 207 & 16992 & 255 & 1567 & NA & NA \\
\hline 1978 & NA & NA & NA & NA & NA & NA \\
\hline 1979 & NA & NA & NA & NA & 86694 & 150 \\
\hline 1980 & NA & NA & NA & NA & NA & NA \\
\hline 1981 & NA & NA & NA & NA & NA & NA \\
\hline 1982 & NA & NA & NA & NA & NA & NA \\
\hline 1983 & NA & NA & NA & NA & NA & NA \\
\hline 1984 & NA & NA & NA & NA & NA & NA \\
\hline 1985 & 77 & 6128 & 137 & 959 & NA & 30 \\
\hline 1986 & 64 & 5012 & 53 & 387 & NA & 26 \\
\hline 1987 & 47 & 3797 & 51 & 335 & NA & 25 \\
\hline 1988 & 93 & 6582 & 76 & 378 & NA & 37 \\
\hline 1989 & 87 & 5859 & 63 & 442 & NA & 53 \\
\hline 1990 & 104 & 6146 & 55 & 476 & NA & 52 \\
\hline 1991 & 121 & 7271 & 63 & 369 & NA & 48 \\
\hline 1992 & 145 & 7055 & 59 & 260 & NA & 49 \\
\hline 1993 & 105 & 5672 & 50 & 233 & NA & 51 \\
\hline 1994 & NA & NA & NA & NA & NA & NA \\
\hline 1995 & NA & NA & NA & NA & NA & NA \\
\hline 1996 & 21 & 1346 & 9 & 93 & NA & 38 \\
\hline 1997 & 33 & 2180 & 9 & 90 & NA & 28 \\
\hline 1998 & 17 & 1060 & 13 & 97 & NA & 27 \\
\hline 1999 & 19 & 1190 & 7 & 54 & NA & 40 \\
\hline 2000 & 24 & 1218 & 7 & 57 & NA & 31 \\
\hline 2001 & 26 & 1599 & 5 & 35 & NA & 35 \\
\hline 2002 & 32 & 1638 & 3 & 72 & NA & 31 \\
\hline 2003 & 31 & 1634 & 3 & 26 & NA & 28 \\
\hline 2004 & 15 & 859 & 5 & 33 & NA & 22 \\
\hline 2005 & 20 & 1341 & 6 & 39 & NA & 26 \\
\hline 2006 & 42 & 2788 & 5 & 38 & NA & 26 \\
\hline 2007 & 58 & 4213 & 7 & 55 & NA & 30 \\
\hline 2008 & 52 & 2826 & 6 & 54 & NA & 23 \\
\hline 2009 & 25 & 1322 & 5 & 58 & NA & 21 \\
\hline 2010 & 29 & 1564 & 6 & 71 & NA & 24 \\
\hline 2011 & 20 & 1318 & 12 & 110 & NA & 29 \\
\hline 2012 & 17 & 1566 & 14 & 136 & NA & 29 \\
\hline 2013 & 21 & 1879 & 9 & 58 & NA & 29 \\
\hline 2014 & 27 & 1724 & 12 & 124 & NA & 37 \\
\hline 2015 & 16 & 1022 & 5 & 65 & NA & 28 \\
\hline 2016 & 13 & 830 & 6 & 45 & NA & 29 \\
\hline
\end{tabular}


Table A1.3. Raw data of catch and catch value that pound net fishers landed with other gear types than pound nets. Catch is presented in metric ton $(\mathrm{mt})$ and catch value is presented in thousand Swedish krona (TSEK).

$\begin{array}{ccccc}\text { Yr } & \begin{array}{c}\text { Eel catch } \\ (\mathrm{mt})\end{array} & \begin{array}{c}\text { Eel catch value } \\ (\text { TSEK })\end{array} & \begin{array}{c}\text { Other catch } \\ (\mathrm{mt})\end{array} & \begin{array}{c}\text { Other catch value } \\ \text { (TSEK) }\end{array} \\ 1996 & 0,6 & 41 & 22 & 171 \\ 1997 & 0,0 & 0 & 0,5 & 3 \\ 1998 & 0,0 & 0 & 1,2 & 40 \\ 1999 & 0,4 & 26 & 28 & 403 \\ 2000 & 0,0 & 0 & 11 & 140 \\ 2001 & 0,3 & 17 & 19 & 296 \\ 2002 & 0 & 0 & 24 & 363 \\ 2003 & 0 & 0 & 10 & 130 \\ 2004 & 0 & 0 & 6 & 71 \\ 2005 & 0,3 & 18 & 11 & 132 \\ 2006 & 1,5 & 98 & 55 & 208 \\ 2007 & 1,6 & 115 & 36 & 235 \\ 2008 & 1,8 & 97 & 28 & 204 \\ 2009 & 1,2 & 63 & 21 & 114 \\ 2010 & 1,5 & 80 & 32 & 123 \\ 2011 & 1,7 & 110 & 21 & 88 \\ 2012 & 1,8 & 162 & 7 & 92 \\ 2013 & 2,3 & 207 & 3 & 40 \\ 2014 & 3,4 & 217 & 7 & 84 \\ 2015 & 2,8 & 180 & 9 & 120 \\ 2016 & 2,7 & 170 & 4 & 59\end{array}$




\section{Appendix 2.}

Table A2.1. Prices for the eel and four other common species the fishers target at nine different points in time. The unit is Swedish Krona per kilo fish and all values are reported in fixed values (i.e. were compensated for inflation using the Swedish Consumer Price Index (CPI)). Source: Swedish official statistic compiled by Jonas Hentati-Sundberg.

$\begin{array}{cccccc}\text { Yr } & \text { Cod } & \text { Herring } & \text { Eel } & \text { Perch } & \text { Whitefish } \\ 1930 & 7,3 & 4,8 & 47,8 & 16,6 & 26,7 \\ 1940 & 7,3 & 6,6 & 47,4 & 13,7 & 23,6 \\ 1950 & 6,0 & 6,7 & 62,9 & 13,0 & 27,8 \\ 1960 & 7,9 & 5,4 & 61,2 & 11,2 & 22,7 \\ 1970 & 6,2 & 6,5 & 82,0 & 9,3 & 21,1 \\ 1980 & 7,9 & 6,3 & 87,4 & 9,1 & 17,7 \\ 1990 & 13,5 & 2,0 & 59,1 & 10,7 & 16,5 \\ 2000 & 18,0 & 2,5 & 50,8 & 17,7 & 20,2 \\ 2010 & 15,0 & 4,2 & 53,9 & 31,3 & 33,7\end{array}$

